\title{
Isolation and Molecular Identification of Probiotic Bacteria Genus Lactobacillus in an Asian Elephant (Elephas maximus) of Tamil Nadu
}

\author{
A. Senthilkumar ${ }^{1 *}$, M.G. Jayathangaraj ${ }^{2}$, A. Valli $^{3}$, A. Thangavelu ${ }^{4}$, \\ S. Gomathinayagam ${ }^{5}$ and N. Sribalaji ${ }^{6}$ \\ ${ }^{1}$ Farmers Training Centre, Theni-625 531, India \\ ${ }^{2}$ Department of Veterinary Clinical Medicine and Therapeutics, Madras Veterinary College, \\ Chennai-600007, India \\ ${ }^{3}$ Institute of Animal Nutrition, Kottupakkam, Chennai-600007, India \\ ${ }^{4}$ Department of Veterinary Microbiology, Madras Veterinary College, Chennai-600007 \\ ${ }^{5}$ Department of Veterinary Parasitology, Madras Veterinary College, Chennai-600007 \\ ${ }^{6}$ VUTRC, Salem, Tamil Nadu Veterinary and Animal Sciences University, India \\ *Corresponding author
}

\section{A B S T R A C T}

\begin{tabular}{|l|}
\hline K e y w o r d s \\
Probiotic bacteria, \\
Genus \\
Lactobacillus - \\
Culturing and PCR \\
identification- \\
Captive \\
Asian Elephants \\
\hline Article Info \\
\hline $\begin{array}{l}\text { Accepted: } \\
\text { 07 November } 2018 \\
\text { Available Online: } \\
\text { 10 December } 2018\end{array}$
\end{tabular}
plant eating herbivores.
The gastrointestinal tract (GIT) of animals is a
habitat of a complex collection of
microorganisms, with large differences

The gastrointestinal tract (GIT) of animals is a
habitat of a complex collection of
microorganisms, with large differences

The gastrointestinal tract (GIT) of animals is a
habitat of a complex collection of
microorganisms, with large differences

\section{Introduction}

Genus Lactobacillus was common probiotic key genera in gastro intestinal tracts of domestic animals as well as wild animals. The species compositions of probiotic bacteria are vary depending up on the animal species. The aim of this study was to isolate and molecular identification of genus Lactobacillus from dung samples of captive Asian elephants (Elephas maximus) reared in temples of Tamil Nadu state in India. Twenty five fresh dung samples of Asian elephants (Elephas maximus) were aseptically collected from various temples of Tamil Nadu state and transferred immediately to the laboratory. Isolation of Lactobacillus by culturing the dung samples using Lactobacillus MRS Broth M369 and molecular confirmation by PCR using BF1, BR1 and Lacto F, Lacto R primers. After 72 hours incubation, Lactobacillus are appeared as large whitish coloured colonies. On Gram staining, Lactobacillus organisms appeared as Gram positive long slender-rods. PCR revealed evidence of Genus Lactobacillus with amplicon sizes were 233 bp;1550 bp. Since Genus Lactobacillus are common probiotic bacteria in the gastro intestinal tract of between individuals and animal species (Walter 2008). The largest land living herbivores are elephants. The anatomy and physiology of the elephant gastrointestinal tract similar to what is found in the horse, 
where a relative simple stomach is followed by a voluminous small and large intestine required for the function of caecal fermentative digestion through the metabolism of a complex microflora (Bojesen et al., 2006). Lactobacillus probiotic bacteria are considered as important genera in the intestinal tracts of animals. They are common microflora of ruminant herbivores (Russell et al., 2011) and have also been isolated from faeces of marmoset and red-handed tamarin South Africa (Endo et al., 2010 and 2012). Their presence in high numbers is associated with good health status of the host. Lactobacillus is helpful in maintaining appropriate balance of the microbiota in the GIT, reducing the risk of pathogen infection. Lactobacillus represents one of the most dominant groups and some Lactobacillus species are frequently used as the probiotic ingredient for humans and also animals (Turroni et al., 2011; Russell et al., 2011). Lactobacillus occurrence and species composition in different animals is very variable. The objective of this study was to isolate and molecular identification of genus Lactobacillus from dung samples of Asian elephant by culture and PCR technique.

\section{Materials and Methods}

Twenty five Fresh dung samples of Asian elephants (Elephas maximus) collected from various temples of Tamil Nadu state were investigated (Plate 1). Collected dung samples were aseptically transferred in ice bags and transported immediately to the laboratory. Lactobacillus MRS broth M369 was first enriched with Lactic acid supplement FD055 and was used for the screening specimens. The dung samples $(n=25)$ were centrifuged and the concentrated bacterial mass (sediment) were inoculated in enriched Lactobacillus MRS broth M369 and were incubated at $42^{\circ} \mathrm{C}$ for 24 hours. The enriched culture was later streaked in to selective plating media such as Lactobacillus MRS agar M641 developed by
Kristeisen et al., (1925) and modified by Kauffman (1935).

The MRS plates were incubated at $35^{\circ} \mathrm{C}$ at $5 \%$ $\mathrm{CO}_{2}$ level, as recommended by the standard literatures. The colony growth was monitored, on daily basis. After $72 \mathrm{hrs}$ of incubation, smear prepared from developed colonies and stained with Gram staining.

The positive colonies of probiotic bacteria were transferred into $1.5 \mathrm{ml}$ Eppendorf tubes containing $250 \mu \mathrm{l}$ of nuclease free water, mixed well and were centrifuged at $6000 \mathrm{rpm}$ for 5 minutes. After centrifugation, the supernatant was discarded. The pellets were re-suspended with nuclease free water and the tubes were sealed with parafilm. The tubes were kept in boiling water bath at $90^{\circ} \mathrm{C}$ for 10 minutes and were again centrifuged at 6000 rpm for 5 minutes. The supernatant was used as DNA template for confirmation of probiotic bacteria by PCR. These Primers were used for molecular identification of probiotic bacertia Genus Lactobacillus

\section{Polymerase chain reaction $(\mathrm{PCR})$}

The reaction mixtures were prepared in $25 \mu 1$ volumes $(12.5 \mu \mathrm{l}$ of Red dye master mix, $2 \mu \mathrm{l}$ of 10 picomol concentrations of Forward primer and Reverse primer, $4 \mu \mathrm{l}$ of $50 \mathrm{ng}$ concentration of DNA template and $4.5 \mu \mathrm{l}$ Nuclease free water). The PCR amplification was carried out in Eppendorf Mastercycler (Eppendorf, Germany) with the following thermal programmes and the annealing temperature was standardized, according to the primer used.

\section{Agarose gel electrophoresis}

The PCR products were tested for amplification by agarose gel electrophoresis on $1.5 \%$ agarose w/v gels by loading $10 \mu \mathrm{l}$ of PCR product into the wells and $100 \mathrm{bp}$ DNA 
(GeNei) ladder was used as a marker for the products that were less than $1000 \mathrm{bp}$. A current of $120 \mathrm{~V}$ was applied to each gel and the PCR products were visualized under UV trans-illumination (Table 1 and 2).

\section{Results and Discussion}

After 72 hours incubation the colonies of Lactobacillus organisms appeared as large whitish coloured colonies as shown in Plate 2. On Gram staining, the organisms were found to be Gram positive long slender-rods as shown in Plate 3. In this present study, the culture result was similar to that result founded by Biradar et al., (2005). PCR revealed evidences of the Probiotic bacteria Genus Lactobacillus with amplicon sizes were 233 bp and 1550 bp as shown in Plates 4. Tannock (1999); Yin and Zheng (2005) and Ashraf (2009) reported that identification of most of the Lactobacillus by using MRS culture and 16S r-DNA technique was 98-99 $\%$ accurate. Lactobacilli were commonly used as probiotics, either as single species or as mixed culture with other bacteria. Lactobacillus organisms were gram-positive, non -motile, rod shaped organisms that do not produce spores and were acid resistant and thrive in acidic conditions $(\mathrm{pH} 4-5$; neutral $\mathrm{pH}$ is 7.0; blood is at a $\mathrm{pH}$ of 7.2) .

Table.1 PCR primers

\begin{tabular}{|l|}
\hline \multicolumn{2}{|c|}{ Sequence $\left(5^{\prime}-3^{\prime}\right)$} \\
\hline BF1: GAGTTTGATCATGGCTCA G \\
\hline BR1: CGCTTACCTTGTTAGCGACTT \\
\hline Lacto F: TGGAAACAGRTGCTAATACCG \\
\hline Lacto R: GTCCATTGTGGAAGATTCCC \\
\hline
\end{tabular}

Amplicon Sive (bp)
235
232

Reference

(Fungsin et al., 2010)

(Byun et al., 2004)

Table.2 PCR amplification programme

\begin{tabular}{|c|c|c|c|c|c|c|}
\hline \multirow{2}{*}{$\begin{array}{l}\text { Primer } \\
\text { Forward } \\
\text { Reverse } \\
\end{array}$} & \multicolumn{6}{|c|}{ PCR amplification programme } \\
\hline & $\begin{array}{c}\text { Initial } \\
\text { Denaturation }\end{array}$ & $\begin{array}{c}\text { Cyclic } \\
\text { Denaturation }\end{array}$ & $\begin{array}{c}\text { Annealing } \\
\text { Temperature }\end{array}$ & Extension & $\begin{array}{c}\text { Final } \\
\text { Extension }\end{array}$ & Cycle No. \\
\hline \multicolumn{7}{|l|}{ Lactobacillus } \\
\hline BF1 \& BR1 & $\begin{array}{l}94^{\circ} \mathrm{C} \text { for } 5 \\
\text { min. }\end{array}$ & $\begin{array}{l}94^{\circ} \mathrm{C} \text { for } 1 \\
\text { min. }\end{array}$ & $51.7^{\circ} \mathrm{C}$ & $\begin{array}{l}72^{\circ} \mathrm{C} \text { for } \\
1 \mathrm{Min}\end{array}$ & $\begin{array}{l}72^{\circ} \mathrm{C} \text { for } 7 \\
\text { Min }\end{array}$ & 35 cycles \\
\hline Lacto F \& Lacto R & $\begin{array}{l}94^{\circ} \mathrm{C} \text { for } 5 \\
\text { min. }\end{array}$ & $\begin{array}{l}94^{\circ} \mathrm{C} \text { for } 1 \\
\text { min. }\end{array}$ & $59.5^{\circ} \mathrm{C}$ & $\begin{array}{l}72^{\circ} \mathrm{C} \text { for } \\
1 \mathrm{Min}\end{array}$ & $\begin{array}{l}72^{\circ} \mathrm{C} \text { for } 7 \\
\text { Min }\end{array}$ & 35 cycles \\
\hline
\end{tabular}

Plate.1 Collection of dung sample from elephant

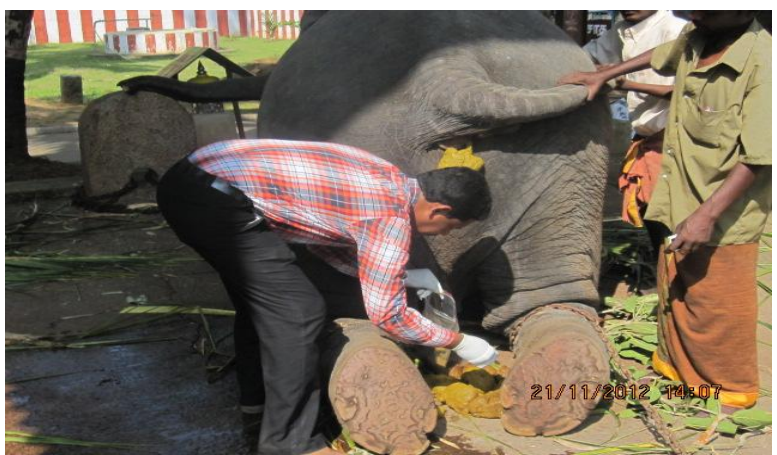


Plate.2 Lactobacillus MRS agar - Lactobacillus (Large whitish Colonies)

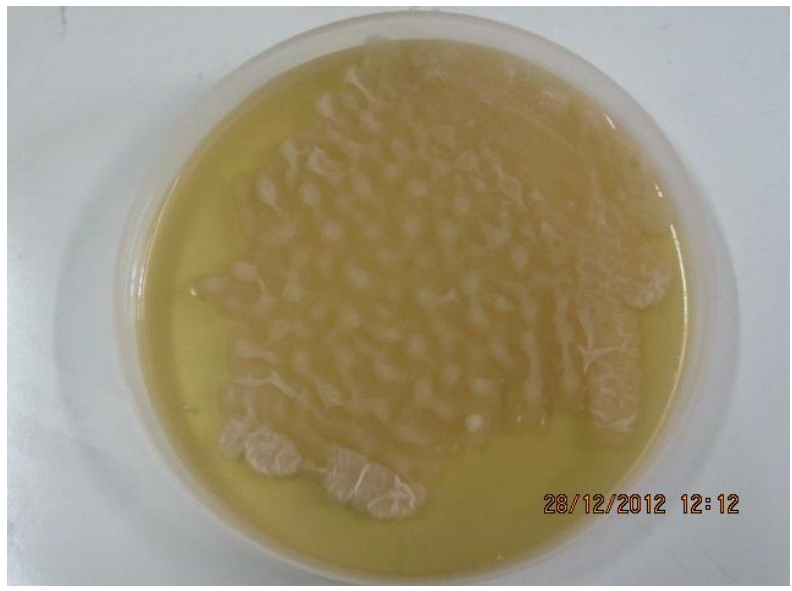

Plate.3 Gram staining-Gram positive long slender-rod-Lactobacillus organisms

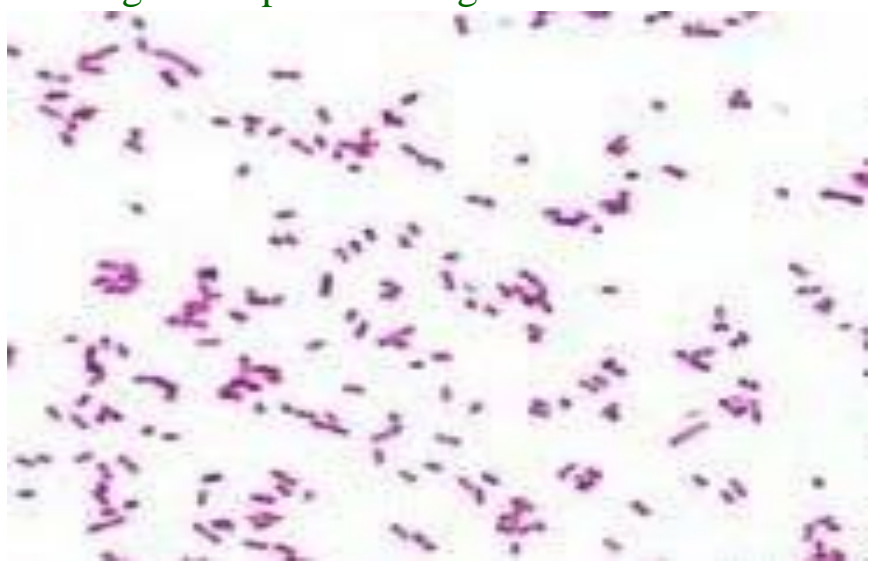

Plate.4 PCR - Identification of genus Lactobacillus

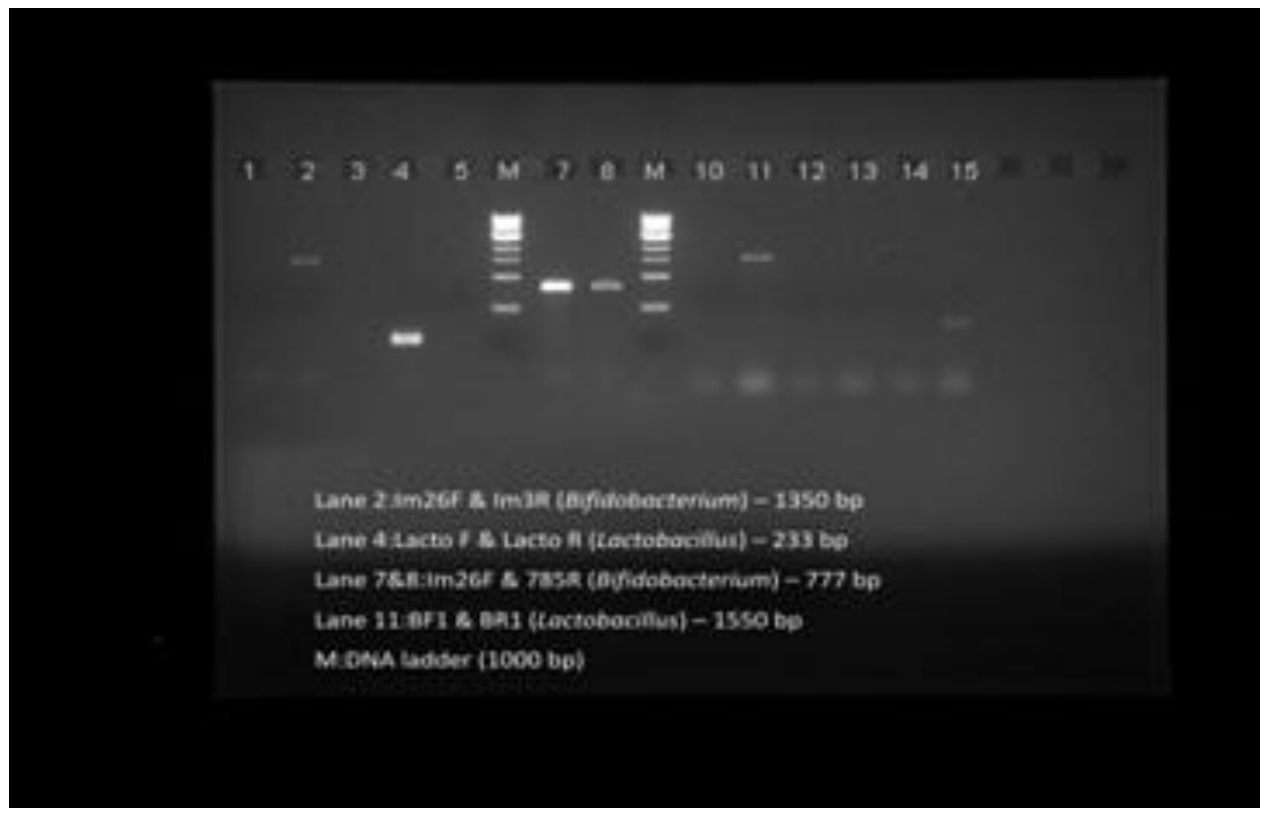


The lactobacillus species were the dominant lactobacillus in the stomach, small intestine, large intestine and faeces/dung of humans and animals and were also found in milk and milk products (Mitsuoka, 1992). The posterior environment of the gut is better for the growth of lactobacilli-like bacteria than the anterior environment due to the low $\mathrm{pH}$ in the stomach, bile salts in the small intestine and oxygen in the faeces. Lactic acid bacteria were reported to reveal several healthpromoting effects on host animals (Ouwehand et al., 2002). Feeding practices and the composition of animal diets can influence the microbial balance and composition of microflora in the gastrointestinal tract (Chaucheyras-Durand and Durand 2010). Lactobacillus species were identified also in the dung of other animals' primary ingesting plants (Russell et al., 2011).

In conclusion, to our knowledge, this study is the first description of Genus Lactobacillus from elephant dung's in India. These isolates were identified as Genus Lactobacillus seems to be common species occurring in the GIT of herbivores including Asian elephants.

\section{References}

Ashraf, M., M. Arshad, M. Siddique and G. Muhammad, 2009. In vitro screening of locally isolated lactobacillus species for probiotic properties. Pakistan Vet. J. 29 (4): $186-190$.

Bojesen, A.M., O. Kep and M.F. Bertelsen, 2006. Fatal enterocolitis in Asian elephants (Elephas maximus) caused by Clostridium defficile. Vet. Microbiol. 116: 329-335.

Chaucheyras-Durand F and Durand H 2010 Probiotics in animal nutrition and health. Beneficial Microbes, 1:3-9

Endo A, Y. Futagawa-Endo andL.M.T. Dicks,2010. Diversity of Lactobacillus and Bifidobacterium in faeces of herbivores, omnivores and carnivores. Anaerobe 16 590-596.

Endo A,Y. Futagawa-Endo, P. Schumann, R. Pukall and L.M.T. Dicks, 2012. Bifidobacterium reuteri sp. nov., Bifidobacterium callitrichos sp. nov., Bifidobacterium saguini sp. nov., Bifidobacterium stellenboschense $s p$. nov. and Bifidobacterium biavatii sp. nov. isolated from feces of common marmoset (Callithrix jacchus) and redhanded tamarin (Saguinus midas).Syst. Appl. Microbiol., 35 92-97.

Kauffmann F., 1935. Weitere Erfahrungen mit dem kombinierten Anreicherungs verfahren für Salmonella enbacillen. $Z$. Hyg. Infektionskr. 117: 26-32.

Kristeisen, M., V. Lester and A. Jurgens, 1925. Use of trypsinized casein, bromothymol blue, bromo-cresol-purple, phenol red and brilliant green for bacteriological nutrient media. Brit. J. Exp. Path., 6: 291-299.

Mitsuoka, T., 1992. The human gastrointestinal tract. In: Wood B.J.B. (ed.): The Lactic Acid Bacteria. Vol.1. The Lactic Acid Bacteria in Health and Disease. Elsevier Applied Science, London. 69-114.

Ouwehand, A.C., S. Salminen and E. Isolauri, 2002. Probiotics: an overview of beneficial effects. Antonie van Leeuwenhoek 82: 279-289.

Russell DA, Ross RP, Fitzgerald GF and Stanton C 2011 Metabolic activities and probiotic potential of bifidobacteria. Int. J. Food Microbiol., 146 88-105.

Tannock, G.W., 1999. Identification of Lactobacilli and Bifidobacteria. Current Issues Molec. Biol. 1(1): 53-64.

Turroni, F., D.V. Sinderen and M. Ventura, 2011.Genomics and ecological overview of the genus Bifidobacterium. International Journal of Food Microbiology 149:37-44.

Walter, J., 2008. Ecological role of 
lactobacilli in the gastrointestinal tract: implication or fundamental and biomedical research. Appl. Environ. Microbiol., 74: 4985-4996

Yin, Q. and Q.O. Zheng, 2005. Isolation and Identification of the dominant
Lactobacillus in Gut and faeces of pig using carbohydrate fermentation and $16 \mathrm{~S}$ r-DNA analysis. Journal of Bioscience and Biotechnology. 99(1): 68-71.

\section{How to cite this article:}

Senthilkumar, A., M.G. Jayathangaraj, A. Valli, A. Thangavelu, S. Gomathinayagam and Sribalaji, N. 2018. Isolation and Molecular Identification of Probiotic Bacteria Genus Lactobacillus in an Asian Elephant (Elephas maximus) of Tamil Nadu. Int.J.Curr.Microbiol.App.Sci. 7(12): 407-412. doi: https://doi.org/10.20546/ijcmas.2018.712.051 